DOI: $10.31393 /$ reports-vnmedical-2020-24(3)-27

UDC: $340.6+343$

\title{
POSSIBILITIES OF USING THE DERMATOGLYPHIC METHOD TO IDENTIFY AN UNKNOWN PERSON (LITERATURE REVIEW)
}

Kozan N. M. ${ }^{1}$, Gunas V. I. ${ }^{2}$, Mishalov V. D. ${ }^{3}$, Voloshynovich V. M. ${ }^{1}$, Chadyk V. $0 .{ }^{1}$

${ }^{1}$ Ivano-Frankivsk National Medical University (2 Halytska Str., Ivano-Frankivsk, Ukraine, 76018),

${ }^{2}$ National Pirogov Memorial Medical University, Vinnytsya (56 Pyrogov street, Vinnytsya, Ukraine, 21018)

${ }^{3}$ Shupyk National Medical Academy of Postgraduate Education (9 Dorohozhytska Str., Kyiv, Ukraine, 04112)

Responsible for correspondence: e-mail:nmkozan@gmail.com

Received: August 03, 2020; Accepted: September 04, 2020

Annotation. The dermatoglyphic method of research, having gone through more than a century of development and transformation, from the stage of application to the comparison of fingerprints and palms to the method of detecting susceptibility to certain diseases, has become an integral, time-tested method in medicine. However, its main field of application is still forensic medicine, in particular, forensic criminalistics and the identification of unknown persons. The emergence of a large number of works and new methods of obtaining and analyzing dermatoglyphic indicators requires a systematic review and analysis in order to organize new knowledge in this area. The analysis of literature sources indicates the rapid development and justification of the use of digital methods to obtain dermatoglyphs of fingers and toes, palms and feet and further processing of digital images, and the use of artificial neural networks to improve expertise to identify an unknown person.

Keywords: dermatoglyphics, identification, forensic medicine.

Currently, there is an intensification of local military conflicts, civil wars, illegal migration, and as a result of an increase in the number of people hiding their identities, an increase in the number of unidentified corpses and parts of corpses, forensic medicine requires a set of modern reliable research methods.

One of the components of this complex is a dermatoglyphic study, a method based on the study and analysis of the ridge pattern of fingers and toes, palms and feet.

From a simple method first used in 1892 by F. Galton to compare fingerprints when using a sheet of paper and a set of inks, this method has now become complex, studying the frequency of patterns, ridge count, frequency of triradii, and so on.

In addition to solving purely forensic or criminalistics questions, dermatoglyphic methods is a powerful tool of medical anthropology, which allows you to answer questions about a person's predisposition to a disease, additional diagnosis of congenital, genetic diseases and more.

In the process of studying corpses, it is not always possible to obtain prints of all areas of the ridge patterns of the skin and study their many features [1], so there is a need to predict the lost, but diagnostically significant parameters. In situations where the parts of the body from which the fingerprints were obtained are separated from each other (explosive trauma, criminal dismemberment, etc.), it is also necessary to address the issue of their anatomical location and belonging to one person in terms of a comprehensive approach to DVI-Interpol.

The works of domestic and foreign researchers have obtained theoretical and practical solutions to this problem
$[10,15]$, proposed a number of methods and models that can be used to detect, recognize and measure the object represented by images. However, despite the existing achievements in the field of image processing and recognition, their application to solve specific practical problems requires additional research. The development and use of models and algorithms for the effective solution of applied problems of image processing requires knowledge of the subject area, the features of the tasks.

Digital camera photography is not the only modern method of colorless dermatoglyphs. There are a large number of applied methods for determining the relief of the hand and foot. At the heart of their differentiation are different physical approaches, and consequently scanners built on them.

In recent years, artificial neural networks have become increasingly popular, based on which identification programs are created, including forensic [8, 13].

Analyzing all the above, we can conclude that the problem of identifying a person using dermatoglyphic parameters in terms of evidence-based medicine is relevant and needs to be addressed. The accumulated results of research in this area require a systematic analysis in order to analyze and compile their main results.

The purpose - based on a review of modern literature, consider the possibilities of the dermatoglyphic method for the identification of unknown persons.

\section{Materials and methods}

In order to achieve this goal, an analysis of literature sources in English, Russian and Ukrainian presented in scientometric databases Google Academy, Scopus, Web of Science for the period 2010-2020 by keywords 
"dermatoglyphics", "identification" have been done.

\section{Results. Discussion}

One of the biggest obstacles to identifying a person is the late absolute signs of death - destruction by animals, mummification and decay. In particular, the latter sharply distorts the features of the face and body and complicates the taking of fingerprints. However, the developed new methods allow to receive full-fledged dermatoglyphs even in the conditions of the expressed rot. Agroup of researchers tested a method of introducing a mixture of balsamic solutions into the wrist vessels with a catheter, which allowed to obtain dermatoglyphs in $76.75 \%$ of cases (sample of 400 corpses) [3].

The research conducted by V. I. Gunas with co-authors $[4,5,6]$ proved that the possibilities of the dermatoglyphic method do not limit the definition of only racial and ethnic affiliation, but also allow to identify administrative-regional affiliation.

Also, this method allows you to obtain information about certain features of human personality, which can be valuable in cases where the inquiry authorities need to establish a "psychological portrait" of the suspect [14].

Most modern research in the field of dermatoglyphics uses digital methods to obtain dermatoglyphs, instead of traditional ones using paint. Specially designed scanners are usually used to obtain fingerprints and palms, and subsequent image processing $[2,12,15]$. Thus, in a study by L. E. Oghenemavwe with co-authors [12] was compared the use of the method of obtaining prints using ink, adhesive tape and digital method. The latter turned out to be the most accurate and simplest according to the results of statistical processing of the obtained data.

To obtain dermatoglyphs of the hands and feet, in particular, the method of I. V. Paliychuk and L. E. Kovalchuk is used in the modification proposed by N. M. Kozan, V. D. Mishalov and Yu. Z. Kotsyubynska [11], where for dermatoglyphic examination of the palms and foot use images of the whole palm and the upper third of the plantar surface of the foot. The obtained results are transferred to a personal computer, where they are processed with the help of graphic programs, studying the qualitative and quantitative indicators of dermatoglyphs of hands and feet (Fig. 1).

Digital images allow to obtain a clear image of the ridge pattern of the distal phalanges of the fingers, because when obtaining fingerprints by the traditional method, its defects are possible (fuzzy, blurred, missing fragment), and when counting the number of ridge and deltas you can enlarge the image, construct vectors folds of the palms, etc.

For example, Futronic's FS80 used in the works of N. M. Kozan [10] reads fingerprints using advanced CMOS technology of an optical sensor to capture high-quality images of fingerprints. The scanner can capture almost without distortion of gray fingerprint images on a computer for $100 \mathrm{~ms}$, which allows you to use this product for any

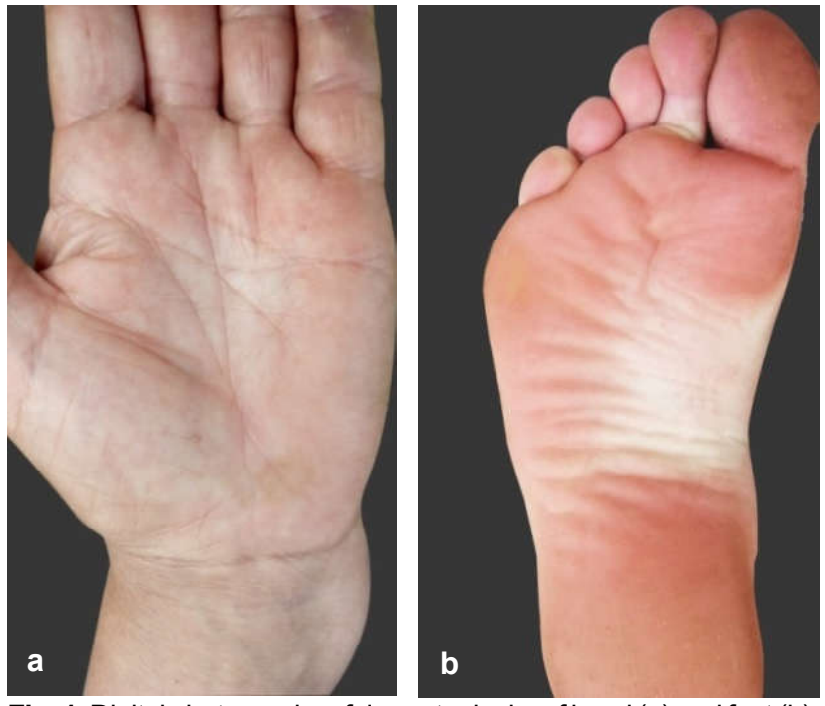

Fig. 1. Digital photographs of dermatoglyphs of hand (a) and feet (b).

application that requires fingerprint identification.

Fig. 2 shows the dermatoglyphs of the distal phalanges of the fingers, obtained using a scanner Futronic's FS80.

For example, in Futronic's FS80, the task of software is to convert a bitmap image into a vector image. During this process, there is a possibility of misinterpretation of the pixel matrix data, so the choice of algorithm (or software) that is suitable for processing photos with papillary pattern is extremely important (Fig. 3).

In general, the software algorithm used to convert a bitmap image to a vector (of varying degrees of detail) can be implemented in different programming languages.

Today, there is a wide range of different software that can improve image quality. The most common and powerful tool in digital image processing is the Adobe product package - AdobeCreativeCloud. In our work we used Photoshop SS and Illustrator CC. These programs have a large number of tools that can improve the image quality in a particular case, but usually for a satisfactory result it is necessary to use several of them: increase (decrease) contrast, lighting, focusing and more. For these actions, there are usually enough built-in functions in photo editors (Fig. 4).

The purpose of improving image quality is to obtain reliable data for further statistical processing. Researchers solve data processing problems in different ways, but in most cases this stage is reduced to filling the database (array) of data, its structuring and formalization with further processing in programs for statistical analysis.

Thus, when identifying an unknown person by dermatoglyphic parameters, the following algorithm should be followed:

- Obtain finger dermatoglyph images by scanning with a scanner.

- Obtain dermatoglyphs of the palms and foot using macro imaging of the entire palm and the upper third of the plantar surface of the foot. 

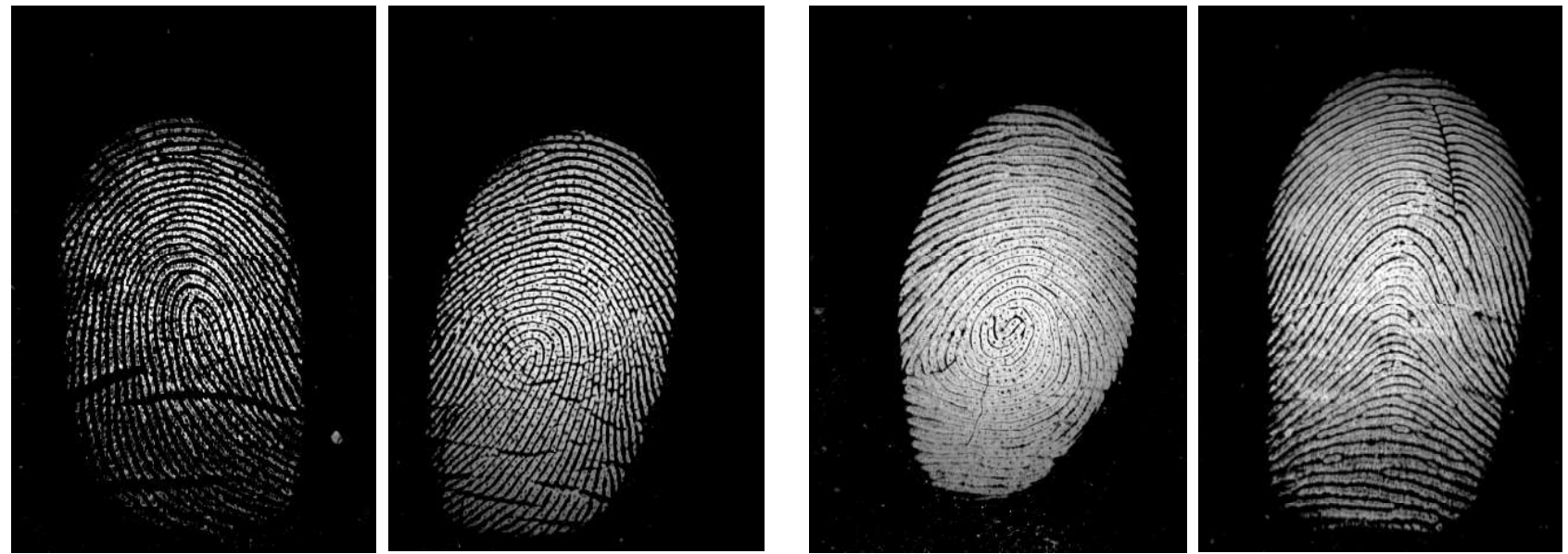

Fig. 2. Dermatoglyphs obtained with a scanner Futronic's FS80.
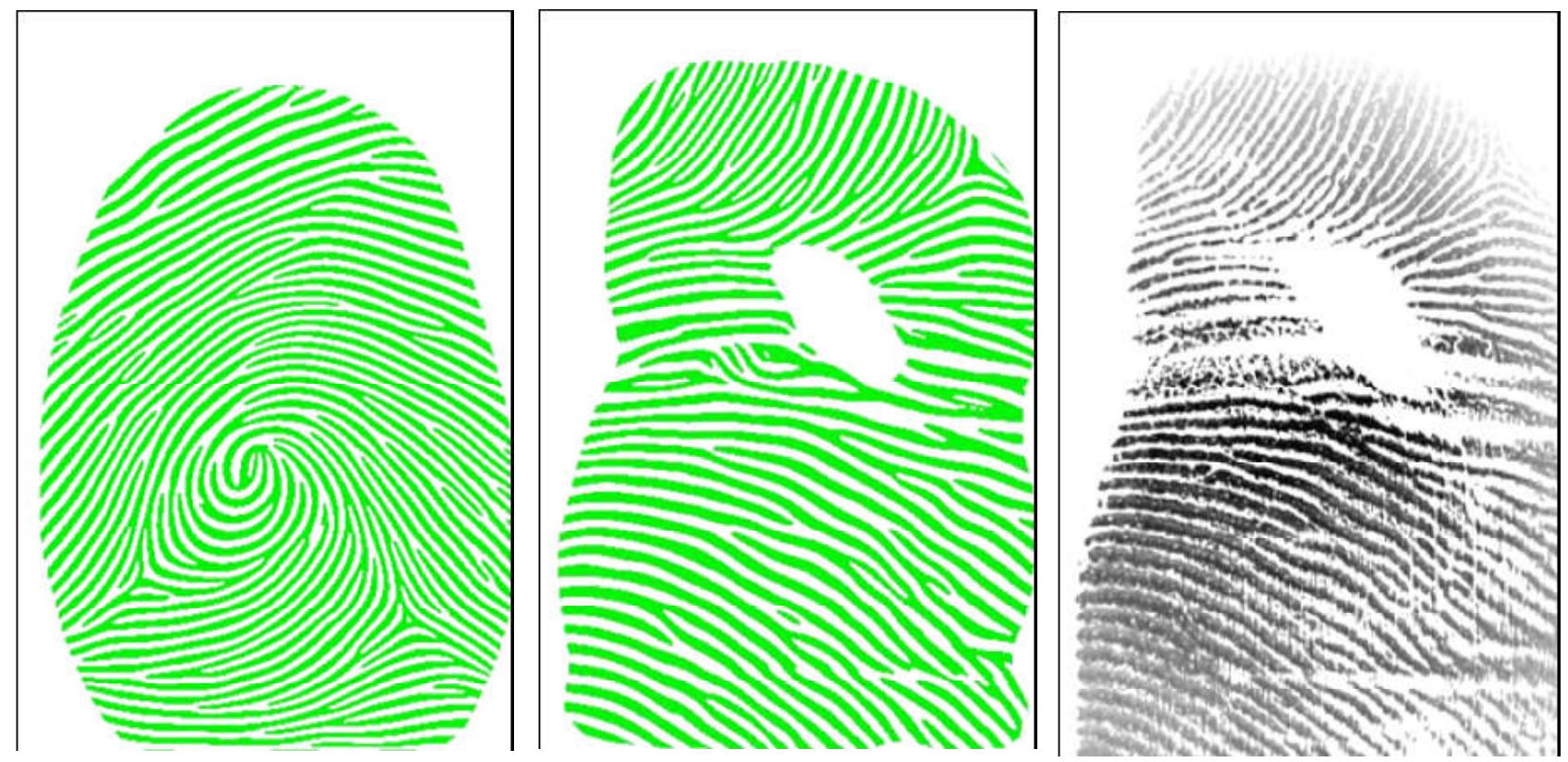

Fig. 3. The resulting vector image obtained using the FIA.

- Transfer the received data to a personal computer, where with the help of graphic programs to process them, studying the qualitative and quantitative indicators of dermatoglyphs of the hand and foot.

- Construction of a neural network. To build a new neural network in STATISTICA, simply enter the appropriate input into the table and select the appropriate item from the NeuralNetworks menu.

- Neural network training. In order to train the neural network, in addition to the input data, it is necessary to add another category of codes, namely "train" for training and "select" for the control subsample. After selecting the target category (for example, Ethnic) and continuous input variables (Al, LUI, Atdl) we get a choice between three strategies for building models (ANS - automated neural network, CNN-user neural network and Subsampling method multiple subsample). For ease of implementation, you should choose an automated neural network. Using

the variable NNSET set the training (train) and control (select) sets. Next, we choose a strategy for creating subsamples with the following input parameters: 5 random subsamples with a relative percentage of $70-15-15 \%$ for training-control-test subsamples. With the activation

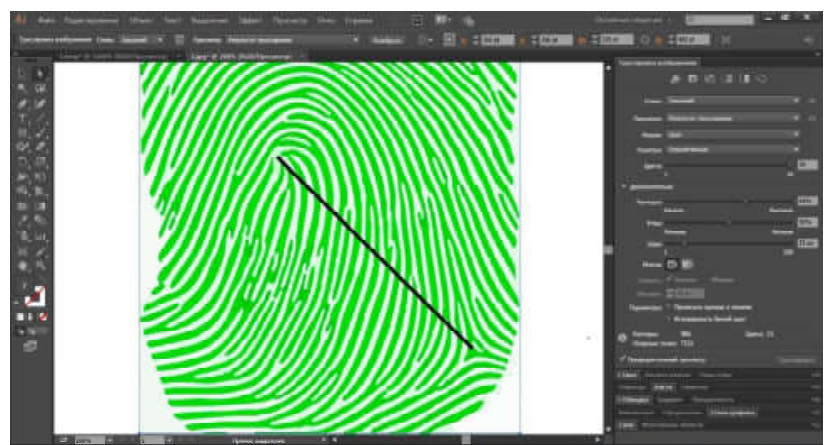

Fig. 4. Materials processing in Adobelllustrator CC. 
functions we choose Logistic, Tanh (logistic, hyperbolic) for the output neurons and Logistic, Tanh, Exponential (logistic, hyperbolic, exponential) - for the hidden ones. Also as initial parameters we specify the number of hidden neurons - from 30 to 50 , the attenuating regularization of neuronal weights (weight decay) - from 0.001 to 0.01 (for hidden layers), the number of networks for learning - 20. All these data are experimentally selected and depending on the type and the complexity of the task can vary widely, which will depend on the tasks.

- Determination of neural network performance. After the training, 5 models of neural networks with different performance indicators will be obtained (percentage of correct classification: the closer this number is to 100 , the better the model classifies the data) of training and test performance. After obtaining the initial results, you can choose the network with maximum learning performance (network with MLP architecture 24-42-3: 24 input, 42 hidden, 3 output neurons). If the result does not suit you (for example, the result obtained $85 \%$ is quite low), it can be improved by switching to the CNN model, where it is allowed to set the refinement input data, namely: RBF network type (radial basis function), 20 training networks, number of neurons 50 , number of epochs 10000 , interactive training for visual analysis of errors is enabled. Such operations can be performed until the test performance and learning performance will not satisfy us in terms of their performance.

- Selection of the resulting network. To correctly select the resulting network, you should also pay attention not only to the test performance, but also to the error matrix. Analysis of the resulting neural network includes the construction of confidence levels for all samples. We should also emphasize the analysis of the importance (sensitivity analysis) of variables that are part of our neural network. For example, it will follow from the analysis that the sign of $\mathrm{Wr}$ of one parameter is more important in forecasting than other parameters. That is, in further analysis, when we reconfigure the model, we must pay more attention to the feature Wr. A lot of data on the quality of network classification can be obtained from elevator maps (Liftcharts), as well as from graphs that allow you to build a software package

\section{References}

1. Bozhchenko, A. P., \& Tolmachev, I. A. (2011). Novyiy algoritm ustanovleniya krovnogo rodstva na osnove dermatoglificheskogo metoda [A new algorithm for establishing consanguinity based on the dermatoglyphic method]. Sudebnomeditsinskaya ekspertiza - Forensic-medical examination, 54 (6), 19-22. Vzyato s https://www.forens-med.ru/ book.php?id=2687

2. Charles, A., Ramani, P., Sherlin, H. J., Dilip, S., Srinivas, S., \& Jayaraj, G. (2018). Evaluation of dermatoglyphic patterns using digital scanner technique in skeletal malocclusion: A descriptive study. Indian Journal of Dental Research, 29 (6), 711. doi: 10.4103/ijdr.IJDR_137_18

3. Gahr, B., Drewitz, $\bar{M}$., Voth, R., \& Ritz-Timme, S. (2013). Quality improvement of fingerprints of decayed corpses by local thanatopractical processing (Thanatoprint). GMS

\section{STATISTICA.}

N. M. Kozan and co-authors [9] developed and implemented a computer identification program Dermatoglyphics For Prediction (DFP), which is based on artificial neural networks. It does not require significant budgetary costs for data acquisition, training of its maintenance specialists, and the construction of the neural network, its training and examination are short in time. In the course of the study, the probability of the obtained results ranged from $73-90 \%$ (automatically calculated by the DFP software), which is significantly higher than the previously obtained results.

Prospects for the use of artificial neural networks are also considered in the works of foreign authors [7, 8, 13]. In the work of Indian scientists, such a network has achieved success in $91.45 \%$ in determining the gender of the subjects. In another study conducted by Kanojia M. and coauthors, these figures were $78 \%$ and $82 \%$ for men and women, respectively [8].

Thus, the information we received during the study of literature sources, allowed us to come close to the creation of real systems for processing and predicting the general phenotypic characteristics of man based on its dermatoglyphic parameters. It is established that the main attention should be paid to the choice of network architecture, method of training and systematization of input data, software package in which the neural network will be created and work.

\section{Conclusions and prospects for further development}

1. The possibilities of the dermatoglyphic method for the identification of unknown persons have expanded and allow to obtain information about the racial, ethnic and regional affiliation of a person, personality traits and other aspects of a person's mental activity.

The use of an identification algorithm, which involves the construction of artificial neural networks that allows, with a minimum set of identification features, to predict lost parameters and the use of digital technologies to obtain dermatoglyphs are promising areas of forensic examination.

Interdisciplinary plastic and reconstructive surgery DGPW, 2. doi: $10.3205 /$ iprs 000035

4. Gunas, V. I. (2018). Modeling using discrimination analysis, priority of practically healthy men to northern or other administrativeterritorial regions of Ukraine on the basis of dermatoglyphic indicators features. World of medicine and biology, 1 (63), 914. doi: 10.26724/2079-8334-2018-1-63-9-14

5. Gunas, V. I., Mishalov, V. D., Serebrennikova, O. A., \& Klimas, L. A. (2018). General phenotypological picture of the finger dermatoglyphics of Ukrainian men: the contribution of individual regions. Reports of Morphology, 24 (4), 41-6. doi: 10.31393/ morphology-journal-2018-24(4)-06

6. Gunas, V. I., Mishalov, V. D., Serebrennikova, O. A., Klimas, L. A., \& Shayuk, A. V. (2018). Palmar dermatoglyphics of modern Ukrainians: regional trends. Biomedical and biosocial 
anthropology, 31, 11-7. doi: 10.31393/bba31-2018-02

7. Gupta, S., \& Rao, A. P. (2014). Fingerprint based gender classification using discrete wavelet transform \& artificial neural network. International Journal of Computer Science and mobile computing, 3 (4), 1289-96. Retrieved from https:/l www.semanticscholar.org/paper/Fingerprint-Based-GenderClassification-Using-\% 26 - Gupta-R a o/ f601d52520ddaf06f37c78820a907c8663a39548

8. Kanojia, M., Gandhi, N., Armstrong, L. J., \& Suthar, C. (2017). Fingerprint based gender identification using digital image processing and artificial neural network. In International Conference on Intelligent Systems Design and Applications. (pp. 1018-1027). Springer, Cham. doi: 10.1007/978-3-31976348-4 98

9. Kozan, N. M., Kotsyubynska, Y. Z., \& Zelenchuk, G. M. Certificate № 74561. Kompiuterna prohrama "Sudovo-medychna identyfikatsiina prohrama $z$ vykorystanniam shtuchnykh neironnykh merezh" [Certificate № 74561. Computer program "Forensic identification program using artificial neural networks"]. Data reiestratsii 07.11.2017.

10. Kozan, N., Kotsyubinskaya, J., \& Zelenchuk, G. (2017). Express prediction of external distinctive features of person using the program of dermatoglyphics for prediction. EUREKA: Health Sciences, 3, 26-32. doi: 10.21303/2504-5679.2017.00329

11. Kozan, N. M., Mishalov, V. D., \& Kotsyubynska, Y. Z. (2015). Patent Ukrainy № 99773 [Patent of Ukraine № 99773]. Sposib otrymannia dermatohlifiv ruk ta nih [Method of obtaining dermatoglyphs of hands and feet]. Kyiv: Derzhavne patentne vidomstvo Ukrainy - Kyiv: State Patent Office of Ukraine.

12. Oghenemavwe, L. E., \& Gloria, Odigwe. (2020). Analysis of Dermatoglyphic Features: Comparison of the Ink, Lipstick and Improvise Digital Methods. Asian Journal of Advanced Research and Reports, 14 (3), 6-16. doi: 10.9734/ajarr/2020/v14i330331

13. Sahu, S., Rao, A. P., \& Mishra, S. T. (2015). Fingerprints based gender classification using adaptive neuro fuzzy inference system. In 2015 International Conference on Communications and Signal Processing (ICCSP). (pp. 1218-1222). IEEE. doi: 10.1109/ICCSP.2015.7322700

14. Serebrennikova, O. A., Gunas, V. I., Klimas, L. A., Ocheretna, N. P., \& Shayuk, A. V. (2019). Predictive assessment of the association of dermatoglyphic indicators with indicators of personality traits, established by factor analysis. Reports of Morphology, 25 (1), 12-8. doi: 10.31393/morphology-journal2019-25(1)-02

15. Tom, R. J., Arulkumaran, T., \& Scholar, M. E. (2013). Fingerprint based gender classification using 2D discrete wavelet transforms and principal component analysis. International Journal of Engineering Trends and Technology, 4 (2), 199203. Retrieved from http://ijettjournal.org/archive/ijett-v4i2p224

\section{Список посилань}

1. Божченко, А. П., \& Толмачев, И. А. (2011). Новый алгоритм установления кровного родства на основе дерматоглифического метода. Судебномедицинская экспертиза, 54 (6), 19-22. Взято с https://www.forens-med.ru/ book. php?id=2687

2. Charles, A., Ramani, P., Sherlin, H. J., Dilip, S., Srinivas, S., \& Jayaraj, G. (2018). Evaluation of dermatoglyphic patterns using digital scanner technique in skeletal malocclusion: A descriptive study. Indian Journal of Dental Research, 29 (6), 711. doi: 10.4103/ijdr.IJDR_137_18

3. Gahr, B., Drewitz, M., Voth, R., \& Ritz-Timme, S. (2013). Quality improvement of fingerprints of decayed corpses by local thanatopractical processing (Thanatoprint). GMS Interdisciplinary plastic and reconstructive surgery DGPW, 2. doi: 10.3205/iprs000035

4. Gunas, V. I. (2018). Modeling using discrimination analysis, priority of practically healthy men to northern or other administrativeterritorial regions of Ukraine on the basis of dermatoglyphic indicators features. World of medicine and biology, 1 (63), 914. doi: $10.26724 / 2079-8334-2018-1-63-9-14$

5. Gunas, V. I., Mishalov, V. D., Serebrennikova, O. A., \& Klimas, L. A. (2018). General phenotypological picture of the finger dermatoglyphics of Ukrainian men: the contribution of individual regions. Reports of Morphology, 24 (4), 41-6. doi: 10.31393/ morphology-journal-2018-24(4)-06

6. Gunas, V. I., Mishalov, V. D., Serebrennikova, O. A., Klimas, L. A., \& Shayuk, A. V. (2018). Palmar dermatoglyphics of modern Ukrainians: regional trends. Biomedical and biosocial anthropology, 31, 11-7. doi: 10.31393/bba31-2018-02

7. Gupta, S., \& Rao, A. P. (2014). Fingerprint based gender classification using discrete wavelet transform \& artificial neural network. International Journal of Computer Science and mobile computing, 3 (4), 1289-96. Retrieved from https:// www.semanticscholar.org/paper/Fingerprint-Based-GenderCIassification-Using-\% $26-$ Gupta-R a o / f601d52520ddaf06f37c78820a907c8663a39548

8. Kanojia, M., Gandhi, N., Armstrong, L. J., \& Suthar, C. (2017). Fingerprint based gender identification using digital image processing and artificial neural network. In International Conference on Intelligent Systems Design and Applications. (pp. 1018-1027). Springer, Cham. doi: 10.1007/978-3-31976348-4_98

9. Козань, Н. М., Коцюбинська, Ю. З., \& Зеленчук, Г. М. Сертифікат № 74561. Комп'ютерна програма "Судово-медична ідентифікаційна програма з використанням штучних нейронних мереж". Дата реєстрації 07.11.2017.

10. Kozan, N., Kotsyubinskaya, J., \& Zelenchuk, G. (2017). Express prediction of external distinctive features of person using the program of dermatoglyphics for prediction. EUREKA: Health Sciences, 3, 26-32. doi: 10.21303/2504-5679.2017.00329

11. Козань, Н. М., Мішалов, В. Д., \& Коцюбинська, Ю. 3. (2015). Патент України № 99773. Спосіб отримання дерматогліфів рук та ніг. Київ: Державне патентне відомство України.

12. Oghenemavwe, L. E., \& Gloria, Odigwe. (2020). Analysis of Dermatoglyphic Features: Comparison of the Ink, Lipstick and Improvise Digital Methods. Asian Journal of Advanced Research and Reports, 14 (3), 6-16. doi: 10.9734/ajarr/2020/v14i330331

13. Sahu, S., Rao, A. P., \& Mishra, S. T. (2015). Fingerprints based gender classification using adaptive neuro fuzzy inference system. In 2015 International Conference on Communications and Signal Processing (ICCSP). (pp. 1218-1222). IEEE. doi: 10.1109/ICCSP.2015.7322700

14. Serebrennikova, O. A., Gunas, V. I., Klimas, L. A., Ocheretna, N. P., \& Shayuk, A. V. (2019). Predictive assessment of the association of dermatoglyphic indicators with indicators of personality traits, established by factor analysis. Reports of Morphology, 25 (1), 12-8. doi: 10.31393/morphology-journal2019-25(1)-02

15. Tom, R. J., Arulkumaran, T., \& Scholar, M. E. (2013). Fingerprint based gender classification using $2 \mathrm{D}$ discrete wavelet transforms and principal component analysis. International Journal of Engineering Trends and Technology, 4 (2), 199203. Retrieved from http://ijettjournal.org/archive/ijett-v4i2p224

\section{МОЖЛИВОСТІ ВИКОРИСТАННЯ ДЕРМАТОГЛІФІЧНОГО МЕТОДУ ДЛЯ ІДЕНТИФІКАЦІЇ НЕВІДОМОЇ ОСОБИ (ОГЛЯД} ЛІТЕРАТУРИ)

Козань Н. М., Гунас В. І., Мішалов В. Д., Волошинович В. М., Чадюк В.О.

Анотація. Дерматогліфічний метод дослідження, пройшовши більш ніж столітню історію розвитку та перетворень, від 
етапу застосування для зіставлення відбитків пальців та долонь до методу виявлення схильності до тих чи інших захворювань, став невід'ємним доказовим, перевіреним часом методом на озброєнні медицини. Проте, досі основною сфрерою застосування його є судова медицина, зокрема, судово-медична криміналістика і питання ідентифікації невідомих осіб. Поява великої кількості робіт і нових методів отримання та аналізу дерматогліфічних показників вимагає системного огляду і аналізу з метою упорядкування нових знань у даній галузі. Проведений аналіз літературних джерел вказує на стрімкий розвиток та обгрунтування використання цифрових методів з метою отримання дерматогліфів пальців рук та ніг, а також долонь та стоп та подальшою обробкою цифрових зображень, і використання итучних нейронних мереж для покращення експертиз, направлених на ідентифікацію невідомої особи.

Ключові слова: дерматогліфіка, ідентифікація особи, судова медицина.

\section{ВОЗМОЖНОСТИ ИСПОЛЬЗОВАНИЯ ДЕРМАТОГЛИФИЧЕСКОГО МЕТОДАДЛЯ ИДЕНТИФИКАЦИИ НЕИЗВЕСТНОГО ЛИЦА (ОБЗОР ЛИТЕРАТУРЫ) \\ Козань Н. Н., Гунас В. И., Мишалов В. Д., Волошинович В. М., Чадюк В. А.}

Аннотация. Дерматоглифический метод исследования, пройдя более чем столетнюю историю развития и преобразований, от этапа применения для сопоставления отпечатков пальцев и ладоней к методу выявления предрасположенности к тем или иным заболеваниям, стал неотъемлемым доказательным, проверенным временем способом на вооружении медицины. Однако, до сих пор основной сферой применения его является судебная медицина, в частности, судебно-медицинская криминалистика и вопросы идентификации неизвестных лиц. Появление большого количества работ и новых методов получения и анализа дерматоглифических показателей требует системного обзора и анализа с целью упорядочения новых знаний в данной области. Проведенный анализ литературных источников указывает на стремительное развитие и обоснование использования цифровых методов с целью получения дерматоглифов пальцев рук и ног, а также ладоней и стоп и последующей обработкой цифровых изображений, и использование искусственных нейронных сетей для улучшения экспертиз, направленных на идентифрикацию неизвестных лиц.

Ключевые слова: дерматоглифика, идентификация личности, судебная медицина. 